Прегледни чланак

Andrej M. Mićović, Ph.D., Assistant Professor

University of Kragujevac

Faculty of Hotel Management and Tourism in Vrnjačka Banja

andrej.micovic@kg.ac.rs

\title{
CONSUMER RIGHT TO PRODUCT ACCESSIBILITY
}

Abstract: In order to reduce barriers in cross-border trade, stimulate the functioning of the internal market, increase the availability of certain products, enable all consumers to have access to certain products on an equal basis, Directive (EU) 2019/882 on the accessibility requirements for products and services has been adopted. With regard to product accessibility article provides an overview of the origins and development of the right to access(ibility), as well as terminological and conceptual analysis of universal design as an constitutional element of the accessibility right and finally article analyzes the rules contained in the Directive regarding: scope of the rules governing product accessibility; accessibility requirements; elements that exclude application of the accessibility requirements.

Keywords: product, availability, accessibility, accessibility requirements, universal design.

\section{INTRODUCTION}

Making products accessible ${ }^{1}$ requires certain pre-conditions to be fulfilled. Firstly, product needs to be placed on the market, and available ${ }^{2}$ for distribution,

${ }^{1}$ The term accessibility can be defined in a broader and narrower sense. In a broader sense, accessibility is best defined as the provision of flexibility to accommodate each user's needs and preferences. In a narrower sense, when used in the context of persons with disabilities, accessibility refers to any place, space, item or service, whether physical or virtual, that is easily approached, reached, entered, exited, interacted with, understood or otherwise used by persons of varying disabilities. Thus, accessibility is not only an inherent right of persons with disabilities, but a means of ensuring that persons with disabilities are able to exercise all rights and fundamental freedoms and are empowered to participate fully in society on equal terms with all others. In this regard, it can be said that accessibility is precondition for persons with disabilities to exercise their consumer rights, including the right to satisfaction of basic needs, like all other consumers. See. United Nations, Accessibility and Development - Mainstreaming disability in the post-2015 development agenda, 2013, 3, https://www.un.org/disabilities/documents/accessibility_and_development.pdf, 1.7.2020.

${ }^{2}$ In legal sources, the term availability is used in different contexts. Besides it is used to indicate that the product is placed on the market (Art. 3, para. 1, item 16 of EU Directive 2019/882 
consumption or use. Issues related to availability of products are regulated by Decision no. 768/2008/EC on a common framework for the marketing of products, and repealing Council Decision 93/465/EEC. ${ }^{3}$ This Decision sets out the common framework of general principles and reference provisions for the drawing up of Community legislation harmonising the conditions for the marketing of products (Community harmonisation legislation) (Art. 2). A marking by which the manufacturer indicates that the product is in conformity with the applicable requirements set out in Community harmonisation legislation providing for its affixing is called the „CE marking” (Annex I, Art. R1, point 16 of the Decision). ${ }^{4}$ Manufacturers and importers who place defective products on the market, i.e. products not in conformity with Community harmonisation legislation are liable for the damage caused in accordance with the rules contained in the Council Directive 85/374/EEC of 25 July 1985 on the approximation of the laws, regulations and administrative provisions of the Member States concerning liability for defective products. ${ }^{5}$ Secondly, certain requirements need to be met in order to raise the level of availability of certain products. This creates the pre-conditions that everyone, including the disabled and the elderly, ${ }^{6}$ has access to certain products and services under equal terms. Product accessibility based on the principles of universal design ${ }^{7}$ is an

on the accessibility requirements for products and services; Art. R1, para. 1, item 1 Annex I of EU Decision No. 768/2008), the term availability is used in the context of consumer's right to satisfaction of basic needs (Article 2 of the Law on Consumer Protection, Off. Gazette of RS, No. 62/14, $6 / 16$ - other law and 44/18 - other law). So, in the first case, it is used in terms of placing products on the market, and in the second in terms of procurement, disposal of certain products and services.

${ }^{3}$ OJ L 218, 13.8.2008, p. 82-128.

${ }^{4}$ The CE mark affixed to the product indicates that the product meets the essential requirements in terms of safety and health of users, property and environmental protection requirements. The CE mark is, in fact, a guarantee that the product complies with all the essential requirements of the European New Approach directives that apply to it, as well as that a conformity assessment has been carried out to prove that the essential requirements have been met. See. CE znak - pasoš za proizvode, https://api.pks.rs/storage/assets/CE\%20znak\%20-\%20Brosura_fin.pdf, 8, 1.7.2020.

${ }^{5}$ OJ L 210, 7.8.1985, p. 29-33.

${ }^{6}$ About 80 million citizens of the European Union are affected by some form of disability. See. Europski akt o pristupačnosti proizvoda i usluga, https://www.hsucdp.hr/europski-akt-o-pristupacnosti-proizvoda-i-usluga-european-accessibility-act/, 1.7.2020.

${ }^{7}$ Universal design is based on the principles of: equitable use (the design is useful and marketable to people with diverse abilities; flexibility in use (the design accommodates a wide range of individual preferences and abilities; simple and intuitive use (use of the design is easy to understand, regardless of the user's experience, knowledge, language skills, or current concentration level; perceptible information (the design communicates necessary information effectively to the user, regardless of ambient conditions or the user's sensory abilities; tolerance for error (the design minimizes hazards and the adverse consequences of accidental or unintended actions; low physical effort (the design can be used efficiently and comfortably with minimum fatigue; size and space for approach and use (appropriate size and space is provided for approach, reach, manipulation, and use regardless of user's body size, posture, or mobility. These principles were established in 1997 by a working group at North Carolina State University led by Ronald Mace and composed of architects, product 
essential step for inclusion of disabled persons in society and facilitation of independent living for people with reduced functional ability. ${ }^{8}$

Following the adoption of the UN Convention on the Rights of Persons with Disabilities (UNCRPD), to which the EU and its Member States are party, the EU has adopted the European Strategy for Persons with Disabilities for the period 2010-2020 ${ }^{9}$ setting out the EU's disability policy framework combined with the legal framework consisted of numerous rules on accessibility governing various areas, including transport, public procurement, electronic communications, networks and services, and labor relations..$^{10}$ The last piece of legislation that ensure the accessibility of products and services at the EU level is Directive 2019/882/EU on the accessibility requirements for products and services. ${ }^{11}$ The purpose of the Directive is to contribute to the proper functioning of the internal market by approximating the laws, regulations and administrative provisions of the Member States as regards accessibility requirements for certain products and services by, in particular, eliminating and preventing barriers to the free movement of products and services covered by this Directive arising from divergent accessibility requirements in the Member States (Art. 1). ${ }^{12}$

With regard to product accessibility article provides an overview of the origins and development of the right to access(ibility), as well as terminological and conceptual analysis of universal design as an constitutional element of the accessibility right and finally article analyzes the rules contained in the Directive regarding: scope of the rules governing product ${ }^{13}$ accessibility; accessibility requirements; elements that exclude application of the accessibility requirements.

designers, engineers and environmental design researchers. See. Sara Frug, „Toward Inclusive Design for Visual Law”, Journal of Open Access to Law, 1/2019, 4; Mary A. Hums et al, „Universal design: Moving the Americans with Disabilities Act from Access to Inclusion", Journal of Legal Aspects of Sport, 1/2016, 41). These principles have been accepted and further developed by the Center for Universal Design under the auspices of North Carolina State University. See. The seven principles, http:// universaldesign.ie/What-is-Universal-Design/The-7-Principles/, 1.7.2020

${ }^{8}$ The concept of 'persons with functional limitations' includes persons who have any physical, mental, intellectual or sensory impairments, age related impairments, or other human body performance related causes, permanent or temporary, which, in interaction with various barriers, result in their reduced access to products and services, leading to a situation that requires those products and services to be adapted to their particular needs (Preamble No. 4 of the Directive 2019/882/EU).

${ }^{9}$ Silvia Favalli, Delia Ferri, ,Defining Disability in the EU Non-Discrimination Legislation: Judicial Activism and Legislative Restraints", European Public Law, 3/2016, https://ssrn.com/abstract $=2659829,1.7 .2020$.

${ }^{10}$ Andrea Broderick, Delia Ferri, International and European Disability Law and Policy, Cambridge University Press, Cambridge, United Kingdom, 2019, 3-4.

${ }^{11}$ OJ L 151, 7.6.2019, p. 70-115.

${ }^{12}$ In order to ensure the consistency of Union law, this Directive should be based on Decision No 768/2008/EC, since it concerns products already subject to other Union acts (Preamble No. 54 of the Directive).

${ }^{13}$ Product means a substance, preparation, or good produced through a manufacturing process, other than food, feed, living plants and animals, products of human origin and products of 


\section{DEVELOPMENT OF THE RIGHT TO ACCESS(IBILITY)}

Accessibility is a precondition for persons with disabilities to live independently and participate fully and equally in society, i.e. to exercise human rights (civil, economic, social and cultural). Without access to the physical environment, to transportation, to information and communication, including information and communications technologies and systems, and to other facilities and services open or provided to the public, persons with disabilities would not have equal opportunities for participation in their respective societies. Historically, the persons with disabilities movement has argued that access to the physical environment and public transport for persons with disabilities is a precondition for freedom of movement, as guaranteed under Art. 13 of the Universal Declaration of Human Rights and Art. 12 of the International Covenant on Civil and Political Rights. Similarly, access to information and communication ${ }^{14}$ is seen as a precondition for freedom of opinion and expression, as guaranteed under article 19 of the Universal Declaration of Human Rights and Art. 19, para. 2, of the International Covenant on Civil and Political Rights. ${ }^{15}$

The first legally binding act at the international level that introduced accessibility as one of the fundamental legal principles is the UN Convention on the Rights of Persons with Disabilities. With regard to accessibility, there are two opposing views in legal doctrine as to whether Art. 9 of the Convention constitutes a new human right or whether it is only concretization of the existing right of access previously mentioned in several international human rights conventions. ${ }^{16}$ The possible reason behind the opposing doctrinal views may be alternative wording of paragraph 11 of the Draft General Comment on Art. 9. of the UNCRPD. ${ }^{17}$ According to the first variant of the proposed text, accessibility should not be viewed as a new right, as some basic human rights documents recognize the right of access to services and facilities open to the public, but accessibility should be seen in the context of the

plants and animals relating directly to their future reproduction (Art. 3. para. 1, item 2 of the Directive).

${ }^{14}$ The term information and communication technologies (ICT) can include any information and communication device (radio, television, satellite, mobile phones, fixed lines, computers, network hardware and software) or an application and its content. See. Committee on the Rights of Persons with Disabilities, General comment No. 2/2014, Article 9: Accessibility, https://digitallibrary.un.org/record/812025/files/CRPD_C_GC_2-EN.pdf, 2, 1.7.2020).

${ }^{15}$ Ibidem, 1.

${ }^{16}$ Art. 25 (c) of the International Covenant on Civil and Political Rights (access to public service) and Art. 5 (f) of the International Convention on the Elimination of All Forms of Racial Discrimination (the right of access to any place or service intended for use by the general public, such as transport hotels, restaurants, cafes, theatres and parks).

${ }^{17}$ Committee on the Rights of Persons with Disabilities, Draft General comment on Article 9: Accessibility, https://undocs.org/pdf?symbol=CRPD/C/11/3, 2013, 4, 1.7.2020. 
right of access, seen from the specific perspective of disability. According to the second variant, UNCRPD constitutes a new right, a right to accessibility, which goes beyond the scope of previously established precedents introduced by earlier human rights treaties. ${ }^{18}$ By adopting General Comment No. 2/2014, the view that accessibility is not a new right prevailed, i.e. that accessibility should be viewed in the context of the right to access, which in this case refers to the protection of persons with disabilities..$^{19}$ According to this view, accessibility is in fact a reaffirmation of the social aspect of the right of access. ${ }^{20}$ Contrary to the official interpretation, the theory points out that there is not a sufficient legal basis for bringing accessibility under the previously established right to access because the scope and content of these two normative concepts are fundamentally different. On the one hand, the right to access ensures that all individuals can use or enjoy goods or services without discrimination and on an equal footing with others. On the other hand, accessibility is a concept that refers to people with disabilities, and in addition, in terms of content, it significantly exceeds the scope of the right to access. Namely, in the context of accessibility, the UNCRPD introduces new and numerous obligations for both signatory states directly and for the private sector indirectly, so it cannot be said that the existing human rights have only been reformulated and expanded. These are therefore newly established obligations that were not previously provided for in international conventions on human rights, and which are important for exercising all other rights (civil, political, economic, social and cultural). ${ }^{21}$

The right to accessibility is being developed as a multidimensional concept that implies technical/physical accessibility, availability, affordability. Technical/ physical accessibility of products, as one of the most important elements of the right to accessibility is achieved through the obligation of manufacturers to provide universal product design for the widest range of people, including people with disabilities, and where necessary the obligation to provide special assistive technologies to guarantee accessibility in certain situations and for a certain group of people. Availability implies not only technical/physical accessibility of products, but also user awareness about their existence, ${ }^{22}$ which is indirectly provided

\footnotetext{
${ }^{18}$ Anna Lawson, „Accessibility obligations in the UN convention on the rights of persons with disabilities: Nyusti \& Takacs v. Hungary”, South African Journal on Human Rights, 2/2014, 381.

${ }^{19}$ Committee on the Rights of Persons with Disabilities, General comment No. 2/2014, Article 9: Accessibility, https://digitallibrary.un.org/record/812025/files/CRPD_C_GC_2-EN.pdf, 4-5, 1.7.2020.

${ }^{20}$ Ibidem, 2.

${ }^{21}$ Andrea Broderick, „Of rights and obligations: the birth of accessibility”, The International Journal of Human Rights, 4/2020, 396-400.

22 Obtaining product information for consumers with some form of physical or mental impairment is rather difficult in practice, which significantly limits their shopping choices and consumer independency. Consequently, they are excluded from making informed market decisions without the assistance of persons without such impairment. See. Ieva Eskytė, „Disabled People's
} 
by access to information and communication technologies. ${ }^{23}$ Finally, it should be ensured that accessible products are available at affordable price. ${ }^{24}$

\section{UNIVERSAL DESIGN AS A CONSTITUTIONAL ELEMENT OF THE RIGHT TO ACCESSIBILITY}

The development of the right to accessibility can be indirectly observed by considering the terms and concepts used by regulators, academics, practitioners and professional organizations to designate design of the product as a constitutive element of the right to accessibility. ${ }^{25}$ Among the heterogeneous terms that are often viewed as synonyms in the conceptual sense, several can be singled out: barrier-free design, accessible design, universal design, design for all, inclusive design.

The forerunner of the concept of universal design is the so-called barrierfree design, which originated in America in the 1950s, after a large number of wounded in the Vietnam War began to return home. The focus of this concept was on removing obstacles (physical barriers) in the built environment for people with disabilities. ${ }^{26}$ Over time, the basis of this concept has been expanded and the emphasis has been placed on social policy with the aim of achieving greater inclusion and integration of persons with disabilities into the community.

During the 1970s, accessible design was recognized for the first time as a condition for exercising civil rights in the United States. At the legislative level, the

\footnotetext{
Vulnerability in the European Single Market: The Case of Consumer Information", Journal of Consumer Policy, 4/2019, 533-536.

${ }^{23}$ In order to ensure the accessibility of information and communication technologies, the UNCRPD obliges States Parties to take appropriate measures to: promote other appropriate forms of assistance and support to persons with disabilities to ensure their access to information; promote access for persons with disabilities to new information and communications technologies and systems, including the Internet; promote the design, development, production and distribution of accessible information and communications technologies and systems at an early stage, so that these technologies and systems become accessible at minimum cost. See: Art. 9. para. 2. point f, $\mathrm{g}$, $\mathrm{h}$ of the UNCRPD.

${ }^{24}$ A. Broderick, D. Ferri, 134.

25 The theory points out that the relationship between accessibility, which refers to access, and universal design, which primarily refers to use, is not most clearly defined by the UNCRPD. In the case of Given v. Australia, the UN Committee on the Protection of Persons with Disabilities points out that access and use are two different elements within the obligation of signatory states to ensure the accessibility of information and communication technologies. However, the Committee does not comment on whether the use presupposes access, whether these are mutually exclusive elements or whether access can be subsumed under use. See: Anthony G. Giannoumis, Michael Ashley Stein, „Conceptualizing universal design for the information society through a universal human rights lens", International Human Rights Law Review, 1/2019, 38-66. Available at: https://oda.oslomet.no/bitstream/handle/10642/8228/Conceptualizing \%252Buniversal\%252Bdesign $\% 252 \mathrm{Bfor} \%$ 252Bthe\%252Binformation\%252B.pdf?sequence=2\&isAllowed=y, 20, 1.7.2020.

${ }^{26}$ M. Hums et al, 39.
} 
terms accessibility and accessible design were used for the first time with the adoption of the Americans with Disabilities Act in 1991. ${ }^{27}$ At that time, appropriate standards were introduced to ensure that buildings, facilities, rail passenger cars, and vehicles are accessible, in terms of architecture and design, transportation, and communication, to individuals with disabilities. ${ }^{28}$ Ten years later, the term affordable design came into international use with the publication of Guidelines for standards developers to address the needs of older persons and persons with disabilities by the International Organization for Standardization (ISO) and the International Electronic Commission (IEC). In addition, the term accessible design has been internationally defined for the first time as a design focused on principles of extending standard design to people with some type of performance limitation to maximize the number of potential customers who can readily use a product, building or service which may be achieved by: designing products, services and environments that are readily usable by most users without any modification; making products or services adaptable to different users (adapting user interfaces); having standardized interfaces to be compatible with special products for persons with disabilities. ${ }^{29}$

The origin of the term universal design is attributed to the architect Ronald Mace, who defined it in the late 1990s as a design of products and environments to be usable by all people, to the greatest extent possible, without the need for adaptation or specialized design. ${ }^{30}$ With the adoption of the UNCRPD in 2006, the term universal design ${ }^{31}$ became internationally recognized, referring not only to products and environments ${ }^{32}$ but also to programmes and services. ${ }^{33}$ This ter-

${ }^{27}$ Hans Persson et al., ,Universal design, inclusive design, accessible design, design for all: different concepts - one goal? On the concept of accessibility - historical, methodological and philosophical aspects", Universal Access in the Information Society, 4/2015, 510.

${ }_{28}$ Americans with Disabilities Act. Section 12204, https://www.ada.gov/pubs/adastatute08. $p d f$, 1.7.2020.

${ }^{29}$ ISO/IEC GUIDE 71:2001(E), Guidelines for standards developers to address the needs of older persons and persons with disabilities, 2001, 2, https:/www.iso.org/files/live/sites/isoorg/files/ archive/pdf/en/iso_iec_guide_71_2001.pdf, 1.7.2020.

${ }^{30} \mathrm{See}$. What is universal design, https://universaldesign.org/definition, 1.7.2020.

${ }^{31}$ Apart from the legislative level, there are numerous definitions of universal design given by professional organizations. From these definitions, one can single out the one given by the Institute for Human-Centric Design, according to which universal design is a framework for the design of places, things, information, communication and policy to be usable by the widest range of people operating in the widest range of situations without special or separate design. Most simply, universal design is human-centered design of everything with everyone in mind. See. Institute for Human-Centered Design, Universal Design Case Studies, https://universaldesigncasestudies.org/ about-project, 1.7.2020.

${ }^{32}$ Universal design encompasses five distinct environments including physical aspects of a facility or a space (built environment, information environment, and communication environment) as well as intangible aspects (policy environment and attitudinal environment). See. Hums et al, 40.

${ }^{33}$ Universal design shall not exclude assistive devices for particular groups of persons with disabilities where this is needed (Art. 2, para. 1, point 5 of the UNCRPD). Furthermore, accessi- 
minological and conceptual definition of universal design was then widely accepted in other documents adopted at the international and EU level, first in the Guide for addressing accessibility in standards published by the ISO and IEC in 2014, where it is used in parallel with the separate term accessible design, ${ }^{34}$ and then in the Directive 2019/882/EU, where it is used as a synonym with the term design for all. ${ }^{35}$ Although the term design for all is not specifically defined at the EU level, the most widely accepted definition is given by the former European Institute of Design and Disability (EIDD - Design for All Europe since 2006). Under that definition, design for all is understood as a design for human diversity, social inclusion and equality. ${ }^{36}$

The term inclusive design ${ }^{37}$ is used primarily in the UK, ${ }^{38}$ where it was established as a new standard BS 7000-6 in 2005 39 and defined by the British Standards Institution (BSI) in the Guide to managing inclusive design. Inclusive design means a comprehensive, integrated design which encompasses all aspects of a product used by consumers of diverse age and capability in a wide range of con-

bility should not exclude the provision of reasonable accommodation when required by Union law or national law (Preamble No. 50 of the Directive). Reasonable accommodation means necessary and appropriate modification and adjustments not imposing a disproportionate or undue burden, where needed in a particular case, to ensure to persons with disabilities the enjoyment or exercise on an equal basis with others of all human rights and fundamental freedoms (Art. 2, para. 1. Point 4 of the Law on the Ratification of the UN Convention on the Rights of Persons with Disabilities).

${ }^{34}$ ISO/IEC GUIDE 71:2014(E), Guide for addressing accessibility in standards, 2014, 3, https://www.iec.ch/webstore/freepubs/isoiecguide71\%7Bed2.0\%7Den.pdf, 1.7.2020. Hereinafter: ISO/IEC, 2014.

${ }^{35}$ Preamble No. 50 and 90 of the Directive 2019/882/EU.

${ }^{36}$ Design for All has roots both in Scandinavian functionalism in the 1950s, ergonomic design from the 1960s, Scandinavian welfare policies, which in Sweden in the late 1960s gave birth to the concept of „A society for all” referring primarily to accessibility. This ideological thinking was streamlined into the UN Standard Rules on the Equalization of Opportunities for Persons with Disabilities, adopted by the UN General Assembly in December 1993. The focus of the UN Standard Rules on accessibility in a clear equality context has inspired the development of the Design for All philosophy, which became a generally accepted concept in EIDD at its Annual General Meeting in Barcelona in 1995. See. Stockholm Declaration, https://dfaeurope.eu/wordpress/wpcontent/uploads/2014/05/stockholm-declaration_english.pdf, 1.7.2020; The EIDD Stockholm Declaration 2004, http://dfaeurope.eu/what-is-dfa/dfa-documents/the-eidd-stockholm-declaration-2004/10/, 1.7.2020.

${ }^{37}$ Inclusive design was first mentioned as a term in theory in 1994 as part of a scientific paper: R. Coleman, The Case for Inclusive Design - an Overview, $12^{\text {th }}$ Triennial Congress International Ergonomics Association and the Human Factors Association of Canada, Toronto, Canada, 1994. See. John P. Clarkson, Roger Coleman, „History of Inclusive Design in the UK”, Applied Ergonomics, 2015, Part B, 239.

${ }^{38} \mathrm{H}$. Persson et al, 7.

${ }^{39}$ New British Standard addresses the need for inclusive design, https://www.bsigroup.com/ en-GB/about-bsi/media-centre/press-releases/2005/2/New-British-Standard-addresses-the-needfor-inclusive-design/, 1.7.2020. 
texts. BS 7000-6 is relevant to all types of products and services, and to the business processes involved in their creation, fabrication, delivery and sustenance in the market, throughout the products lifecycle from conception to final disposal, including management of obsolescence. ${ }^{40}$

Terms such as barrier-free design, accessible design, universal design, design for all, inclusive design, are often used interchangeably in practice with the same meaning, ${ }^{41}$ although stricto sensu there are certain conceptual differences which can be identified. Unlike the concept of barrier-free design, which refers to removing obstacles in a built environment for the needs of people with disabilities, concepts such as accessible design, universal design, design for all and inclusive design refer to the widest range of users operating in different environments. ${ }^{42}$ The latter concepts are the result of the maturing awareness during the last decade of the XX century that age, ability and life status are not the reason for product inaccessibility, but reasons should be sought in design and environment that do not take into account the full range of human capabilities. ${ }^{43}$

In comparison to the term inclusive design, the terms universal design and design for all may not be the most precise in the semantic sense, because no design can be truly universal to suit everyone. However, justification for these terms should not be sought in semantics but in the aspiration to ensure respect for basic human and consumer rights. Among these rights is the consumer right to satisfaction of basic needs, which is, inter alia, achieved through the right to product accessibility.

\section{LEGAL SCOPE OF THE EU RULES ON PRODUCT ACCESSIBILITY}

Product accessibility rules contained in the Directive 2019/882/EU apply to specific economic operators and products. The duty to ensure availability of the accessible products on the market applies to all economic operators ${ }^{44}$ from public

${ }^{40}$ Standard BS 7000-6:2005 applies to all levels of staff and management in all types of organizations operating in the manufacturing, process, service and construction industries, as well as in public and not-for-profit sectors. See. BS 7000-6:2005 Design management systems, Managing inclusive design, Guide, https:/gala.gre.ac.uk/id/eprint/12997/, 1.7.2020.

${ }^{41}$ ISO/IEC, 2014, 3.

42 The general aim of the concepts such as accessible design, universal design, design for all and inclusive design is to improve the physical and social environment and therefore reduce the need for 'special' provision and 'assistive technologies'. See. Colin Barnes, „Understanding disability and the importance of design for all", Journal of Accessibility and Design for All, 1/2011, 68.

${ }^{43}$ J. P. Clarkson, R. Coleman, 127.

${ }^{44}$ Economic operator means the manufacturer, the authorised representative, the importer, the distributor or the service provider (Art. 3, para. 1, point 21 of the Directive). 
and private sectors ${ }^{45}$ intervening in the supply and distribution chain, and corresponds to their particular role in that process. ${ }^{46}$ Exceptionally, in relation to microenterprises, ${ }^{47}$ which account for $93.1 \%$ of the total number of economic operators, ${ }^{48}$ the obligations and product accessibility requirements are lighter in order to reduce the administrative burden ${ }^{49}$ and facilitate their position. Beneficiaries of the product accessibility rules are consumers, natural persons who purchase $\mathrm{e}^{50}$ the relevant product or who are recipients of the relevant service for purposes which are outside their trade, business, craft or profession. ${ }^{51}$

When it comes to products, the Directive applies to the following products placed on the market after 28 June 2025: a) consumer general purpose computer hardware systems and operating systems for those hardware systems; b) self-service payment terminals and self-service terminals dedicated to the provision of services (automated teller machines; ticketing machines; check-in machines; interactive self-service terminals providing information, excluding terminals installed as integrated parts of vehicles, aircrafts, ships or rolling stock); ${ }^{52} \mathrm{c}$ ) consumer terminal equipment with interactive computing capability, used for electronic communications services; d) consumer terminal equipment with interactive computing capability, used for accessing audiovisual media services; e) e-readers. ${ }^{53}$

${ }^{45}$ Preamble No. 57 of the Directive.

${ }^{46}$ Preamble No. 55 of the Directive.

${ }^{47}$ Microenterprise means an enterprise which employs fewer than 10 persons and which has an annual turnover not exceeding EUR 2 million or an annual balance sheet total not exceeding EUR 2 million (Art. 3, para. 1, point 23 of the Directive).

${ }^{48}$ European Commission, Annual report on European SMEs 2017/2018, 2017, 13, https:// op.europa.eu/en/publication-detail/-/publication/a435b6ed-e888-11e8-b690-01aa75ed71a1/language-en/ format-PDF/source-80656354, 1.7.2020.

${ }^{49}$ Preamble No. 71 of the Directive.

${ }^{50}$ Purchase of the products refers to consumer who buys, orders, receives, uses, resorts to products or is the addressed of product-related commercial communication and offer. Zoltán B. Nagy, Szilvia O. Somsák, „The Micro-and Macro Level Instruments on Financial Consumer Protection in Hungarian Law”, Collected Papers of the Faculty of Law in Novi Sad, 4/2019, 1433.

${ }^{51}$ Art. 3, para. 1, point 22 of the Directive.

52 Member States may provide that self-service terminals lawfully used by service providers for the provision of services before 28 June 2025 may continue to be used in the provision of similar services until the end of their economically useful life, but no longer than 20 years after their entry into use (Art. 32, para. 2 of the Directive).

53 The products within the scope of the Directive were carefully selected in consultation with citizens, civil society organizations and economic operators. Among other things, the goal is to facilitate producers to export products that meet EU requirements because they will not have to adapt them to different national rules. Attempts to make products more accessible to consumers, without taking into account the interests of economic operators, usually do not give good results. Thus, in the Republic of Montenegro, the Law on Consumer Protection (Off. Gazette of Montenegro, 2/14, 6/14 - corr., 43/15 and 70/17) stipulates that data on certain products must be displayed on Braille letter (Art. 7, para. 2, point 4). The Rulebook on the list of products, manner of display and type of facilities in which notices on goods are displayed in Braille, initially determined that 
The determination of the products falling within the scope of this Directive is based on a screening exercise which was carried out during the preparation of the Impact Assessment that identified relevant products and services for persons with disabilities, and for which Member States have adopted or are likely to adopt diverging national accessibility requirements disruptive to the functioning of the internal market (Preamble No. 18 of the Directive). By the adoption of the Directive, two important objectives have been achieved: facilitation of the implementation of the UNCRPD provisions by establishing common Community rules; fulfillment of the national obligations of the Member States under the UNCRPD (Preamble No. 16 of the Directive).

The products falling within the scope of the Directive were also determined taking into account the case law, i.e. the decisions of the UN Committee on the Rights of Persons with Disabilities. For example, in Hungarian case law, issues related to the accessibility of ATMs were considered, ${ }^{54}$ which were ultimately

every other product for personal hygiene and housing hygiene must contain a notice in Braille. At the request of traders, who pointed out that such a solution is non-functional, inapplicable and irrational, initial provision has been amended requiring Braille label to be displayed only on two products (liquid shampoo and laundry/dishwasher detergent), on one-fifth of those products sold in facilities with an area of more than 500 square meters (Rulebook on the list of products, manner of display and type of facilities in which notices on goods are displayed in Braille, Off. Gazette of Montenegro, 30/17, 40/19). See. Europski akt o pristupačnosti proizvoda i usluga, https://www. hsucdp.hr/europski-akt-o-pristupacnosti-proizvoda-i-usluga-european-accessibility-act/, 1.7.2020; Trgovci se žale na primjenu Pravilnika, http://www.disabilityinfo.me/ljudska-prava/pristupacnost/ item/950-ljudska-prava-podkategorija-pristupacnost, 1.7.2020; Pravilnik o listi proizvoda, načinu isticanja i vrsti objekta u kojima se ističu obavještenja o robin a brajevom pismu, https://www. paragraf.me/dnevne-vijesti/02062017/02062017-vijest2.html, 1.7.2020.

${ }^{54}$ Hungarian citizens Szilvia Nyusti and Péter Takács, initiated a civil lawsuit against OTP Bank in 2005, alleging a violation of the right to equal treatment. Under contracts for private current account services which were concluded in 1996 and 2003, they were entitled to use banking cards at ATMs. For the provision of services under the contract, they were paying annual fee at the same rate as non-disabled clients. However, they could not use ATMs on their own, as the keyboards of ATMs operated by OTP were not marked in Braille, nor were audio instructions and voice assistance provided for bank card operations. The first-instance court found that this case was direct discrimination, rejecting OTP's argument that the subsequent equipping of ATMs would constitute positive discrimination, by pointing out that OTP violated the right to human dignity and equal treatment contrary to the Hungarian Equal Treatment Act. The court ordered OTP to retrofit within 120 days at least one of its ATMs in the capital towns of each county, one in each district of Budapest, and four ATMs in the districts where the authors reside and ordered OTP Bank to pay 200,000 Hungarian forints in damages. Although it confirmed that this was discrimination, the Court of Appeals took the position that it was not direct but indirect discrimination and that OTP was not obliged to adjust the ATM or to pay compensation, because it was ,exempted from the obligation to provide equal treatment". The Court of Appeals further held that: intervening in the contractual relationship with a request for subsequent adjustment of the ATM would constitute a violation of the principle of freedom of contract; adjusting ATMs will not ensure that visually impaired people can use them on their own, given the risks it would pose to their personal safety. In 2009, the Hungarian Supreme Court upheld the decision of the Court of Appeals, arguing 
dealt with by the UN Committee on the Rights of Persons with Disabilities in the case of Szilvia Nyusti, Péter Takács and Tamás Fazekas v. Hungary (Communication No. 1/2010). The Committee, acting under Art. 5 of the Optional Protocol to the UNCRPD, ${ }^{55}$ took the position that the State party in the particular case has failed to fulfil its obligations under Art. 9, para. 2(b), of the Convention, governing accessibility. In this regard, the Committee adopted general and specific recommendations. ${ }^{56}$

The general recommendations relate to the obligations of States Parties to take measures to prevent similar violations in the future, including by: (a) establishing minimum standards for the accessibility of banking services provided by private financial institutions for persons with visual and other types of impairments; (b) providing for appropriate and regular training on the scope of the Convention and its Optional Protocol to judges and other judicial officials in order for them to adjudicate cases in a disability-sensitive manner; (c) ensuring that its legislation and the manner in which it is applied by domestic courts is consistent with the State party's obligations to ensure that legislation does not have the purpose or effect of impairing or nullifying the recognition, enjoyment or exercise of any right for persons with disabilities on an equal basis with others. ${ }^{57}$ Special recommendations refer to the obligation of the State party to remedy the lack of

that the authors knew that the ATMs were not accessible before concluding their contracts with OTP Bank and that they nevertheless entered into a contract and agreed to their disadvantaged situation through implied conduct. Having exhausted all effective domestic remedies, the authors submitted a communication to the UN Committee on the Rights of Persons with Disabilities, stating that Hungary had not taken adequate steps to ensure that the relevant legal obligations were interpreted and applied in accordance with the Convention regarding: non-discrimination (including reasonable accommodation) (Art. 5. paragraphs 2 and 3); accessibility (Art. 9); equal recognition before the law and equal right of persons with disabilities to control their own financial affairs and have equal access to bank loans, mortgages and other forms of financial credit (Article 12, paragraph 5). With the exception of Art. 12, the Committee confirmed the merits of the application with regard to Art. 5 and 9, but limited his decision to Art. 9, because the application concerned the accessibility of all ATMs operated by OTP, and not just those in the neighborhood of the authors. See. A. Lawson, 382-384.

55 The Committee shall hold closed meetings when examining communications under the present Protocol. After examining a communication, the Committee shall forward its suggestions and recommendations, if any, to the State Party concerned and to the petitioner. See. Art. 5 of the Law on Ratification of the Optional Protocol to the Convention on the Rights of Persons with Disabilities (Off. Gazette of RS, 42/09).

56 Although the committee's decisions on individual petitions are not binding, they certainly contribute to better protection of human rights. By implementing them, states would take a major step towards even more effective protection of human rights at the international level. See. Bojan N. Tubić, „Postupci pred pojedinim univerzalnim telima UN za zaštitu ljudskih prava - Aktuelna pitanja i perspektive”, Zbornik Pravnog fakulteta u Novom Sadu, 4/2019, 1203.

${ }^{57}$ Committee on the Rights of Persons with Disabilities, Communication No. 1/2010, 14, para. 10, https://www.ohchr.org/Documents/HRBodies/CRPD/Jurisprudence/CRPD-C-9-D-1-2010 en.doc, 1.7.2020. 
accessibility for the authors to the banking card services provided by the ATMs operated by OTP. ${ }^{58}$

\section{APPLICATION AND EXEMPTIONS FROM THE APPLICATION OF THE ACCESSIBILITY REQUIREMENTS}

All products falling within the scope of the Directive must comply with the accessibility requirements ${ }^{59}$ set out in Annex I (Art. 4, para. 2). A distinction is made between general requirements, which apply to all products (Annex I, section I) and requirements, which apply to product packaging and user manual, except that they do not apply to self-service terminals (Annex I, section II).

In order to meet accessibility requirements, products must be: designed and produced to maximise their use by people with disabilities; compliant with detailed rules on information and instructions, user interface and functionality design, support services and packaging. ${ }^{60}$ In addition to the stated accessibility requirements, Directive contains a number of functional performance criteria related to modes of operations of products. Those criteria are not meant as a general alternative to the accessibility requirements of the Directive. Those criteria should apply to specific functions or features of the products or services, to make them accessible, when the accessibility requirements of the Directive do not address one or more of those specific functions or features (Preamble No. 24 of the Directive). ${ }^{61}$

According to the Art. 14, para. 1 of the Directive, the accessibility requirements referred to in Art. 4 shall apply only to the extent that compliance: a) does not require a significant change in a product that results in the fundamental alteration of its basic nature; b) does not result in the imposition of a disproportionate

\footnotetext{
${ }^{58}$ Ibidem

${ }^{59}$ Accessibility requirements should be introduced in the manner that is least burdensome for the economic operators and the Member States (Preamble No. 21 of the Directive).

${ }^{60}$ Accessibility of products and services, https://eur-lex.europa.eu/legal-content/EN/LSU /?uri=CELEX:32019L0882, 1.7.2020.

${ }^{61}$ In this regard, Annex I, Section VII, inter alia, provides that: where the product provides visual modes of operation, it shall provide at least one mode of operation that does not require vision or perception of color; where the product provides auditory modes of operation, it shall provide at least one mode of operation that does not require hearing; where the product or service requires vocal input from users, it shall provide at least one mode of operation that does not require vocal input; where the product requires manual actions, it shall provide at least one mode of operation that enables users to make use of the product through alternative actions not requiring fine motor control and manipulation, hand strength or operation of more than one control at the same time; the operational elements of products shall be within reach of all users so that product suitable for manual mode of operation shall provide at least one mode of operation that is operable with limited reach and limited strength.
} 
burden on the economic operators concerned..$^{62}$ These elements set limits for the application of accessibility requirements.

Economic operators shall carry out an assessment of whether compliance with the accessibility requirements would introduce a fundamental alteration or, based on the relevant criteria set out in Annex VI, impose a disproportionate burden. Assessment should be documented and all relevant results should be kept for a period of five years to be calculated from the last making available of a product on the market. Upon a request from the market surveillance authorities, ${ }^{63}$ the economic operators should provide the authorities with a copy of the assessment (Art. 14, paras. 2 and 3 of the Directive).$^{64}$ Where economic operators refer to corrective elements for a specific product, they should send information to that effect to the relevant market surveillance authorities (Art. 14, para. 8 of the Directive).

In exceptional cases, where the compliance with accessibility requirements of the Directive would impose a disproportionate burden on economic operators, economic operators should only be required to comply with those requirements to the extent that they do not impose a disproportionate burden. Measures that would impose a disproportionate burden should be understood as measures that would impose an additional excessive organisational or financial burden on the economic operator. In assessing the extent to which accessibility requirements cannot be met because they would cause a disproportionate burden, only the legitimate reasons of the economic operator can be taken into account. Lack of priority, time or knowledge should not be considered a legitimate reason. ${ }^{65}$

The above possibility according to which economic entities can be exempted from the obligation to meet the accessibility requirements is in direct conflict with the General Comment No. 2/2014 of the UN Committee on the Rights of Persons with Disabilities, according to which the obligation to implement accessibility is unconditional, which means that an economic entity should not invoke a dispro-

${ }^{62}$ The principle of proportionality, which limits the effect of accessibility requirements, is a general principle, a remedy used when considering various legal issues. See. Aleksandra Popovski, „Uloga načela razmjernosti u ograničavanju temeljnih gospodarskih sloboda unutrašnjeg tržišta", Savremeni pravni promet i usluge (ur. Miodrag Mićović), Kragujevac 2018, 65; Dario Đerđa, „Načelo razmjernosti u donošenju upravnih odluka”, Zbornik Pravnog fakulteta Sveučilišsta $u$ Rijeci, 1/2016, 175.

${ }^{63}$ When carrying out market surveillance of products and checking compliance of services, authorities should also check the conformity assessments, including whether the relevant assessment of fundamental alteration or disproportionate burden was properly carried out. When carrying out their duties authorities should also do so in cooperation with persons with disabilities and the organisations that represent them and their interests (Preamble No. 80 of the Directive).

${ }^{64}$ Microenterprises dealing with products shall be exempted from the requirement to document their assessment. However, if a market surveillance authority so requests, microenterprises dealing with products and which have chosen to rely on Art. 14, para. 1 shall provide the authority with the facts relevant to the assessment (Art. 14, para. 4 of the Directive).

${ }^{65}$ Preamble No. 66 of the Directive. 
portionate burden in order to avoid its obligation. ${ }^{66}$ Leading European organizations for the protection of the rights of persons with disabilities have expressed concern that these exceptions could be used in practice by arbitrary interpretation as an excuse to circumvent the rules of the Directive relating to accessibility requirements. ${ }^{67}$

\section{CONCLUSION}

Product availability, as an element of accessibility, and product availability in the context of the consumer's right to satisfaction of basic needs, have different meaning. In the first case, it is used in terms of placing products on the market, and in the second in terms of procurement, disposal of certain products. Terminological differences raise question whether the consumer's right to product accessibility is a new right that goes beyond the consumer's right to satisfaction of basic needs. It seems that the right to product accessibility is not a new right, but rather a concretization of the right to satisfaction of basic needs, by determining its content and ensuring consumer equality in satisfying basic needs.

By taking into consideration different terms and concepts in the context of product design and the right to accessibility, it can be concluded that the 1990s were a turning point in their understanding. Awareness of demographic aging as a global trend and the broad desire of the community with disabilities to be included in the mainstream of consumer society was then awakened. ${ }^{68}$ Unlike the concept of barrier-free design, which refers to removing obstacles in a built environment for the needs of people with disabilities, concepts such as accessible design, universal design, design for all and inclusive design refer to the widest range of users operating in different environments. The focus of these terminologically different and conceptually related concepts are not only persons with disabilities, but also all other persons falling under the unique term consumer, who do not necessarily have a disability. The emphasis is therefore not on some physical or mental disability, but on product design in accordance with the saying ,good design enables, bad design disables". ${ }^{69}$ In this way, stigmatization and discrimination of certain categories of citizens and consumers is avoided, and protection of their basic human and consumer rights, including the consumer's right to satisfaction of basic needs, ensured.

${ }^{66}$ Committee on the Rights of Persons with Disabilities, 2014, 8.

${ }^{67}$ European Disability Forum, EDF analysis of the European Accessibility Act, 2019, http:// www.edf-feph.org/newsroom/news/our-analysis-european-accessibility-act, 1.7.2020.

${ }^{68}$ Clarkson, Coleman, 127.

${ }^{69}$ The EIDD Stockholm Declaration, 2004, http://dfaeurope.eu/what-is-dfa/dfa-documents/ the-eidd-stockholm-declaration-2004/10/, 1.7.2020. 
Product accessibility is achieved by ensuring that: products are in compliance with the accessibility requirements, products are placed on the market, which means that they have become available; economic operators participating in the supply and distribution chain have fulfilled their obligations regarding accessibility. All products falling within the scope of the Directive 2019/882/EU must, within reasonable limits, comply with accessibility requirements.

Despite the undoubted importance of the rules of the Directive 2019/882/EU on product accessibility, significant drawbacks can be identified which are primarily related to the limited scope of the Directive and numerous exemptions from the application of product accessibility rules: household appliances, as products that have the widest application, were left outside the scope of the Directive; micro-enterprises accounting for $93.1 \%$ of all enterprises in the non-financial business sector are excluded from the scope of the Directive; there are provisions that allow exemptions from the application of product accessibility requirements based on a fundamental alteration of the product, or because of a disproportionate burden for the economic operator (unless they are granted external funding to improve accessibility in accordance with Article 14 (6) of the Directive); the period of transposition by Member States is lengthy and for some of the products implementation is disproportionally long (the deadline for the implementation of the measures is 2025 , whereby self-service terminals that were in use before 28 June 2025 may continue to be used until the end of their economically useful life, but not longer than twenty years after the beginning of their entry into use.

\section{REFERENCES}

Aleksandra Popovski, „Uloga načela razmjernosti u ograničavanju temeljnih gospodarskih sloboda unutrašnjeg tržišta", Savremeni pravni promet i usluge (ed. Miodrag Mićović), Kragujevac 2018, 65-98.

Andrea Broderick, „Of rights and obligations: the birth of accessibility” The International Journal of Human Rights, 4/2020.

Andrea Broderick, Delia Ferri, International and European Disability Law and Policy, Cambridge University Press, Cambridge, United Kingdom 2019.

Anna Lawson, „Accessibility Obligations in the UN Convention on the Rights of Persons with Disabilities: Nyusti \& Takacs v. Hungary", South African Journal on Human Rights, 2/2014.

Anthony G. Giannoumis, Michael Ashley Stein, „Conceptualizing universal design for the information society through a universal human rights lens", International Human Rights Law Review, 1/2019, https://oda.oslomet.no/bitstream/handle/10642/8228/Conceptualizing\%252 Buniversal\%252Bdesign\%252Bfor\% 252Bthe $\% 252$ Binformation\%252B.pdf? sequence=2\&isAllowed=y, 1.7.2020. 
Bojan N. Tubić, „Postupci pred pojedinim univerzalnim telima UN za zaštitu ljudskih prava - Aktuelna pitanja i perspektive", Zbornik radova Pravnog fakulteta u Novom Sadu [Collected Papers of the Faculty of Law in Novi Sad], 4/2019.

Colin Barnes, (2011), „Understanding disability and the importance of design for all”, Journal of Accessibility and Design for All, 1/2011.

Dario Đerđa, „Načelo razmjernosti u donošenju upravnih odluka”, Зборник Правноі

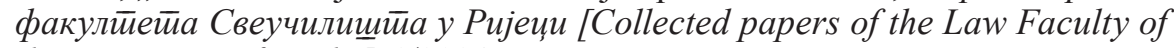
the University of Rijeka], 1/2016.

Hans Persson et al, „Universal design, inclusive design, accessible design, design for all: different concepts - one goal? On the concept of accessibility - historical, methodological and philosophical aspects, Universal Access in the Information Society, 4/2015.

Ieva Eskytè, „Disabled People's Vulnerability in the European Single Market: The Case of Consumer Information", Journal of Consumer Policy, 4/2019.

John P. Clarkson, Roger Coleman, „History of Inclusive Design in the UK”, Applied Ergonomics, Part B, 2015.

John Clarkson, Roger Coleman, „Inclusive design”, Journal of Engineering Design, 2-3/2010.

Mary A. Hums et al, „Universal design: Moving the Americans with Disabilities Act from Access to Inclusion", Journal of Legal Aspects of Sport, 1/2016.

Sara Frug, „Toward Inclusive Design for Visual Law”, Journal of Open Access to Law, 1/2019.

Silvia Favalli, Delia Ferri, „,Defining Disability in the EU Non-Discrimination Legislation: Judicial Activism and Legislative Restraints", European Public Law, 3/2016, https://ssrn.com/abstract=2659829, 1.7.2020.

Zoltán B. Nagy, Szilvia O. Somsák, „The Micro-and Macro Level Instruments on Financial Consumer Protection in Hungarian Law", Collected Papers of the Faculty of Law in Novi Sad (Collected Papers of FLNS), 4/2019.

\section{Serbian Legislation}

Zakon o zaštiti potrošača [Law on Consumer Protection], Službeni glasnik RS [Off. Gazette of RS], No. 62/2014, 6/2016 - other law and 44/2018 - other law

Zakon o potvrđivanju Konvencije o pravima osoba sa invaliditetom [Law on Ratification of the Convention on the Rights of Persons with Disabilities], Službeni glasnik RS [Off. Gazette of RS], No. 42/2009.

Zakon o potvrđivanju Opcionog protokola uz Konvenciju o pravima osoba sa invaliditetom [Law on Ratification of the Optional Protocol to the Convention on the Rights of Persons with Disabilities], Službeni glasnik RS [Off. Gazette of RS], No. 42/2009.

Zakon o ratifikaciji Međunarodne konvencije o ukidanju svih oblika rasne diskriminacije [Law on Ratification of the International Convention on the Elimination of All Forms of Racial Discrimination], Službeni list SFRJ [Off. Gazette SFRY], No. 31/1967.

Zakon o ratifikaciji Međunarodnog pakta o građanskim i političkim pravima [Law on Ratification of the International Covenant on Civil and Political Rights], Službeni list SFRJ [Off. Gazette SFRY], No. 7/1971. 


\section{EU Legislation}

Council Directive 85/374/EEC on the approximation of the laws, regulations and administrative provisions of the Member States concerning liability for defective products, OJ L 210, 7.8.1985, p. 29-33

Decision No 768/2008/EC of the European Parliament and of the Council of 9 July 2008 on a common framework for the marketing of products, and repealing Council Decision 93/465/EEC, OJ L 218, 13.8.2008, p. 82-128

Directive (EU) 2019/882 on the accessibility requirements for products and services, OJ L 151, 7.6.2019, p. 70-115

European Disability Strategy (2010-2020), COM(2010) 636 final

\section{Comparative Legislation}

Americans with Disabilities Act, https://www.ada.gov/pubs/adastatute08.pdf, 1.7.2020. Pravilnik o listi proizvoda, načinu isticanja i vrsti objekata u kojima se ističu obavještenja o robi na Brajevom pismu [Rulebook on the list of products, manner of display and type of facilities in which notices on goods are displayed in Braille], Službeni list CG [Off. Gazette of Montenegro], No. 30/2017, 40/2019.

Zakon o zaštiti potrošača [Law on Consumer Protection], Службени лиси ЦГ [Off. Gazette of Montenegro], No. 2/2014, 6/2014 - corr., 43/2015, 70/2017.

\section{Case Law}

Committee on the Rights of Persons with Disabilities, Communication No. 1/2010, https://www.ohchr.org/Documents/HRBodies/CRPD/Jurisprudence/CRPD-C9-D-1-2010 en.doc, 1.7.2020.

Given v. Australia, CRPD/C/19/D/19/2014

Szilvia Nyusti, Péter Takács and Tamás Fazekas v. Hungary, CRPD/C/9/D/1/2010

\section{Commentary}

Committee on the Rights of Persons with Disabilities, Draft General comment on Article 9: Accessibility, 2013, https://undocs.org/pdf?symbol=CRPD/C/11/3, 1.7.2020.

Committee on the Rights of Persons with Disabilities, General comment No. 2/2014, Article 9: Accessibility, 2014, https://digitallibrary.un.org/record/812025/files/ CRPD_C_GC_2-EN.pdf, 1.7.2020.

Institutional Documents

European Commission, Annual report on European SMEs 2017/2018, https://op.europa.eu/en/publication-detail/-/publication/a435b6ed-e888-11e8-b690-01aa75ed71a1/language-en/format-PDF/source-80656354, 1.7.2020.

European Disability Forum. (2019). EDF analysis of the European Accessibility Act, http://www.edf-feph.org/newsroom/news/our-analysis-european-accessibilityact, 1.7.2020.

ISO/IEC GUIDE 71:2014(E), Guide for addressing accessibility in standards, https:// www.iec.ch/webstore/freepubs/isoiecguide71\%7Bed2.0\%7Den.pdf, 1.7.2020.

ISO/IEC GUIDE 71:2001(E), Guidelines for standards developers to address the needs of older persons and persons with disabilities, https://www.iso.org/files/ live/sites/isoorg/files/archive/pdf/en/iso_iec_guide_71_2001.pdf, 1.7.2020. 
United Nations, Accessibility and Development - Mainstreaming disability in the post-2015 development agenda, 2013, https://www.un.org/disabilities/documents/ accessibility_and_development.pdf, 1.7.2020.

\section{Internet Sources}

Accessibility of products and services, https://eur-lex.europa.eu/legal-content/EN/ LSU/?uri= CELEX:32019L0882, 1.7.2020

BS 7000-6:2005 Design management systems, Managing inclusive design, Guide, https://gala.gre.ac.uk/id/eprint/12997/, 1.7.2020.

CE znak - pasoš za proizvode, https://api.pks.rs/storagelassets/CE\%20znak\%20-\%20 Brosura_fin.pdf, 1.7.2020.

Europski akt o pristupačnosti proizvoda i usluga, https://www.hsucdp.hr/europskiakt-o-pristupacnosti-proizvoda-i-usluga-european-accessibility-act, 1.7.2020.

Institute for Human-Centered Design, Universal Design Case Studies, https://universaldesigncasestudies.org/about-project, 1.7.2020.

New British Standard addresses the need for inclusive design, https://www.bsigroup. com/en-GB/about-bsi/media-centre/press-releases/2005/2/New-British-Standard-addresses-the-need-for-inclusive-design/, 1.7.2020.

Pravilnik o listi proizvoda, načinu isticanja i vrsti objekata u kojima se ističu obavještenja o robi na brajevom pismu, https://www.paragraf.me/dnevne-vijesti/02062017/02062017-vijest2.html, 1.7.2020.

Stockholm Declaration, https://dfaeurope.eu/wordpress/wp-content/uploads/2014/05/ stockholm-declaration_english.pdf, 1.7.2020

The EIDD Stockholm Declaration. (2004), http://dfaeurope.eu/what-is-dfa/dfa-documents/the-eidd-stockholm-declaration-2004/10/, 1.7.2020.

The seven principles, http://universaldesign.ie/What-is-Universal-Design/The-7-Principles/, 1.7.2020.

Trgovci se žale na primjenu Pravilnika, http://www.disabilityinfo.me/ljudska-prava/ pristupacnost/item/950-ljudska-prava-podkategorija-pristupacnost, 1.7.2020.

What is universal design, https://universaldesign.org/definition, 1.7.2020. 
Др Аняреј М. Мићовић, доченй

Универзитиети у Країујевиу

Факулиетеи за хойелијерстиво и ииуризам у Врњачкој Бањи

andrej.micovic@kg.ac.rs

\section{Право потрошача на приступачност производа}

Сажетйак: Раяи смањења баријера у йрекоїраничној йріовини, йобољ-

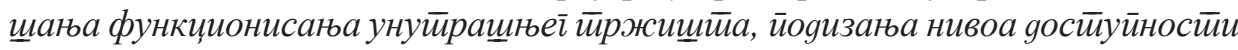

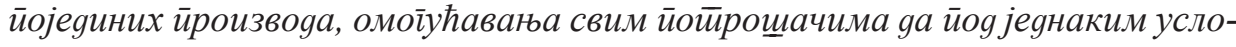

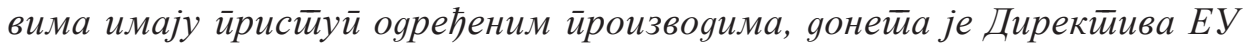

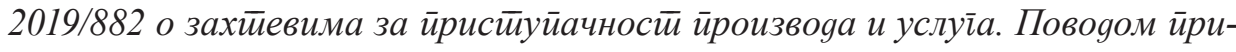

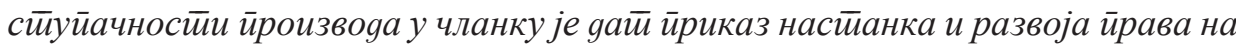

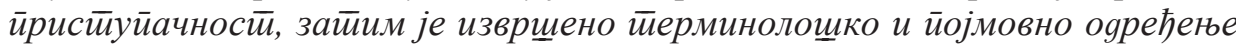

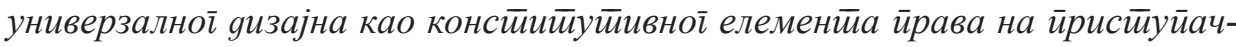
ности и на крају су анализирана иравила из Дирекиииве којима се: оgређује иравни оквир за ирримену ирравила о ирисииуйачносиии ировзвоgа; уйврђују

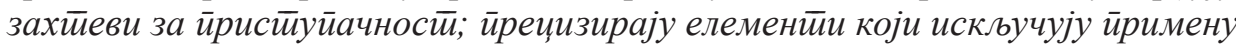

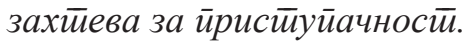

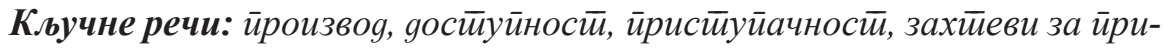

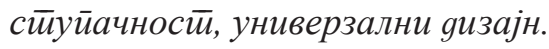

Датум пријема рада: 12.12.2020. 